Egyptian Journal of Rabbit Science, 31(1): 91-106 (2021)

\title{
NUTRITONAL IMPACT OF USING CITRONELLA (CYMBOPOGON NARDUS) BY-PRODUCT WITH OR WITHOUT ENZYMES MIXTURE SUPPLEMENTATION ON GROWTH PERFORMANCE OF GROWING RABBITS.
}

\author{
Amira M. Refaie, Walaa A. Salama M.A. El-Shora and Fatma G. Ahmed \\ Animal Production Research Institute, Agricultural Research Center, El- \\ Dokki, Giza, Egypt. \\ Corresponding author: Amira Refaie E-mail address: amera.refay@arc.sci.eg
}

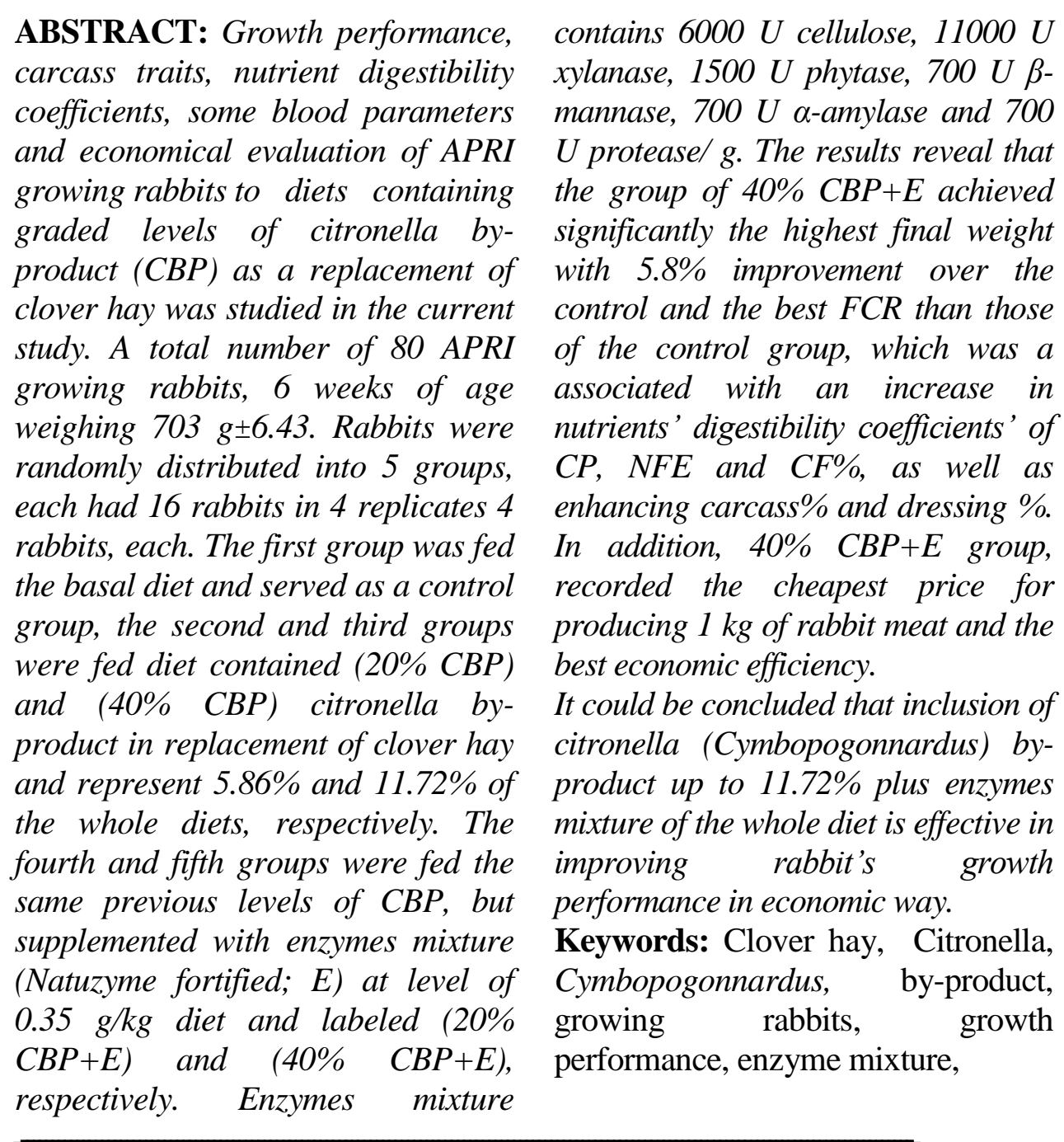




\section{INTRODUCTION}

Cost of feed is the main factor affecting animal production, representing more than $70 \%$ of the total production cost. So, new unconventional local sources of low price ingredients need to be identified and validated.

Citronella grass plant has many common names such as ceylon citronella, giant turpentine grass and nard grass, it belongs to Poaceae family. This grass is grown in the tropical areas of Asia like Indonesia, Java, Burma, India and Sri Lanka (Paranagamaet al., 2003). Since 2006, cultivation of citronella grass succeeded in Egypt, for production of its essential oil. It could be noted that, per each $1000 \mathrm{~kg}$ of distilled citronella leaves, $8 \mathrm{~kg}$ of essential oil will be produced; remaining by-products $(992 \mathrm{~kg})$ are discarded as a waste (Manurung et al., 2015), hence, this waste used for feeding domestic animals. Citronella by-product contains $5.4 \%$ crude protein, $34.2 \%$ crude fiber and $2.3 \%$ ether extract according to Rao et al. (1984), and has many medical benefits such as anti-bacterial, anti-microbial, and anti-fungal (Prabuseenivasan et al., 2006). Also, it acts as antioxidant and growth promoter as reported by Shah et al. (2011).These effects may be due to that it contains some essential oils (such as geraniol (35.7\% of total volatiles), transcitral $(22.7 \%)$, cis-citral (14.2\%), geranyl acetate (9.7\%), citronellal (5.8\%) and citronellol (4.6\%) according to Nakahara et al. (2003).and flavonoids (Lewis, 1986).In earlier research of Rosete et al. (1987) found that daily body weight gain of the holestein-friesian heifers improved by feeding either cymbopogon citrates or citronella bagasse forage comparing to control . In addition to Mohamed (2003) reported that feeding rabbits on cymbopogon citrates by- product at level of $10 \%$ of the diet improved daily body weight gain, feed intake, feed conversion ratio, digestibility coefficient of nutrients and dressing percentage compared to the control group. As citronella grass contains low crude protein, nitrogen free extract, and high crude fiber contents, addition of enzymes mixture is a suitable solution for this problem. In this respect, several studies have been reported that the use of enzyme mixture to improve the utilization of some plant by-products, Ibrahim et al.(2010) reported an enhancement in rabbit's performance by adding enzyme to diet containing date stone meal. Moreover, El-Manylawi and El-Banna (2013) concluded that replacing clover hay in rabbit's diet by 10 or $20 \%$ date stone meal with enzyme mixture improved growth performance comparing to control group.

Therefore, the aim of the present study was to investigate the effect of citronella by-product without or with enzyme mix on growth performance, carcass quality traits, and marketing price of growing rabbits. 


\section{MATERIALS AND METHODS}

The current study was conducted at Sakha Animal Production Research Station, Animal Production Research Institute, Agricultural Research Center, Ministry of Agriculture, Egypt. A total number of 80 APRI growing rabbits, 6 weeks of age weighing $703 \mathrm{~g} \pm 6.43$. Rabbits were kept in cleaned and fumigated cages of wire floored batteries in an open system house under similar conditions of management

\section{Preparation of citronella by-product (CBP)}

After extracting the oil from citronella grass, its by-product was air dried inside an empty room in the farm, turned over in morning and evening until complete dried then citronella by-product was grinded and packed till starting the experiment. The proximate analysis was done according to AOAC (2000) and DE with citronella by-product was calculated according to Cheeke, (1987) as follows:

\section{$\mathrm{DE}(\mathrm{kcal} / \mathrm{kg})=4.36-(0.0491 \times \mathrm{NDF} \%)$, Where $\mathrm{NDF} \%=28.924+$ $(0.657 \times \mathrm{CF} \%)$.}

\section{Natuzyme fortified $(E)$}

Enzyme mixture used in this study was obtained from Bio proton pty Ltd., Australia. Each $1 \mathrm{~g}$ of enzyme mixture (E) used in this study contained: $6000 \mathrm{U}$ cellulose, $11000 \mathrm{U}$ xylanase, 1500 Uphytase, $700 \mathrm{U}$ beta-mannase, $700 \mathrm{U}$ alpha-amylaseand $700 \mathrm{U}$ protease. This product was used at rate of $350 \mathrm{~g} / \mathrm{ton}$.

Experimental rabbits were randomly distributed into 5 groups, each containing 16 rabbits in 4 replicates 4 rabbits each. The $1^{\text {st }}$ group served as the control group. In the other 4 groups, citronella by product (CBP) was used at levels of 20 or $40 \%$ in replacement of clover hay. Each level of CBP was used without enzyme supplementation (CBP) or supplemented with $0.35 \mathrm{~g} / \mathrm{kg}$ diet enzyme mixture $(\mathrm{CBP}+\mathrm{E})$ as an attempt to improve the utilization of $\mathrm{CBP}$ in fattening rabbit diets. All groups were given isocaloric and iso-nitrogenous diets for 8 weeks experimental period. Experimental diets were formulated according to RCFF (2001) (Table 1), also, formulated to satisfy the Agriculture Ministry Decree (1996) recommendations for growing rabbits. Water and pellet experimental feeds were offered ad libitum.

Rabbits were weighed in the beginning (6 weeks of age) initial body weight and at the end (14 weeks of age) final body weight of the growth trial also, feed intake was recorded biweekly. While, weight gain and feed conversion ratio (as $\mathrm{g}$ feed/ $\mathrm{g}$ gain), were calculated. At the end of the 
Table 1: Feed ingredients and calculated analysis of the experimental diets.

\begin{tabular}{|c|c|c|c|c|c|}
\hline Ingredients & Control & $\begin{array}{l}20 \% \\
\text { CBP }\end{array}$ & $\begin{array}{l}40 \% \\
\text { CBP }\end{array}$ & $\begin{array}{c}20 \% \\
\text { CBP+E }\end{array}$ & $\begin{array}{r}40 \% \\
\text { CBP+E }\end{array}$ \\
\hline Clover hay (12\%) & 29.30 & 23.44 & 17.58 & 23.44 & 17.58 \\
\hline $\mathrm{CBP}$ & --------- & 5.86 & 11.72 & 5.86 & 11.72 \\
\hline Wheat bran & 22.00 & 22.00 & 21.50 & 22.00 & 21.50 \\
\hline Yellow corn & 22.00 & 22.00 & 22.00 & 22.00 & 22.00 \\
\hline Soybean meal $(44 \%)$ & 20.00 & 20.00 & 20.50 & 20.00 & 20.50 \\
\hline Vitamin and Mineral mix.* & 0.30 & 0.30 & 0.30 & 0.30 & 0.30 \\
\hline Di calcium phosphate & 2.00 & 2.00 & 2.00 & 2.00 & 2.20 \\
\hline Sodium Chloride & 0.30 & 0.30 & 0.30 & 0.30 & 0.30 \\
\hline Limestone & 0.70 & 0.70 & 0.70 & 0.70 & 0.70 \\
\hline DL-Methionine & 0.35 & 0.35 & 0.35 & 0.35 & 0.35 \\
\hline Anticoccidia(Diclazuril) & 0.05 & 0.05 & 0.05 & 0.05 & 0.05 \\
\hline Molasses & 3.00 & 3.00 & 3.00 & 3.00 & 3.00 \\
\hline Total & 100 & 100 & 100 & 100 & 100 \\
\hline \multicolumn{6}{|l|}{ Calculated analysis \%**** } \\
\hline Organic matter & 90.28 & 90.10 & 89.80 & 90.10 & 89.80 \\
\hline Crude protein & 17.55 & 17.53 & 17.42 & 17.53 & 17.42 \\
\hline Crude fiber & 13.20 & 13.58 & 13.95 & 13.58 & 13.95 \\
\hline Ether extract & 2.64 & 2.79 & 2.87 & 2.79 & 2.87 \\
\hline Nitrogen free extract & 56.89 & 56.20 & 55.56 & 56.20 & 55.56 \\
\hline Ash & 9.72 & 9.90 & 10.20 & 9.90 & 10.20 \\
\hline $\mathrm{DE}(\mathrm{kcal} / \mathrm{kg})$ & 2550 & 2551 & 2553 & 2551 & 2553 \\
\hline Calcium & 1.22 & 1.15 & 1.10 & 1.15 & 1.10 \\
\hline Total phosphorus & 0.84 & 0.83 & 0.82 & 0.83 & 0.82 \\
\hline Lysine & 0.94 & 0.91 & 0.90 & 0.91 & 0.90 \\
\hline Methionine & 0.62 & 0.61 & 0.61 & 0.61 & 0.61 \\
\hline Price/ Ton $(\mathbf{L E})^{* *}$ & 4643 & 4510 & 4380 & 4580 & 4450 \\
\hline \multicolumn{6}{|c|}{ 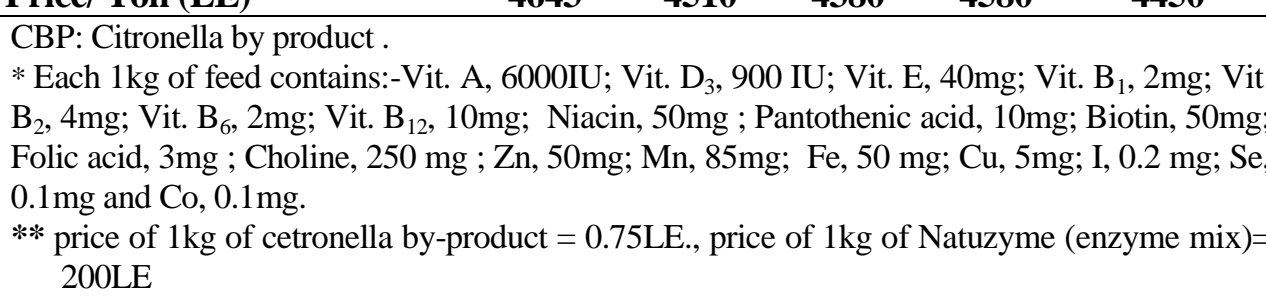 } \\
\hline
\end{tabular}


feeding trial, 20 rabbits, 4 of each treatment (one from each replicate) were randomly chosen and individually housed in metabolic cages to determine the nutrients digestibility and feeding values of dietary treatments. The analyses of feed and dried feces were done according to AOAC (2000).

At the end of the growth trial, 4 rabbits of each experimental group were overnight fasted then assigned for determining hot carcass, dressing, giblets (heart, liver and kidney) as proportioned to live weight of slaughtering. Twenty blood samples were taken into tubes without anticoagulant and centrifuged at $3000 \mathrm{rpm}$ for 15 minutes to obtain serum that stored frozen at $-20^{\circ} \mathrm{C}$ until analyzed for total protein $(\mathrm{TP} ; \mathrm{g} / \mathrm{dl})$, albumin $(\mathrm{g} / \mathrm{dl})$, aspartate amino transferase (AST; $\mathrm{u} / \mathrm{l}$ ), serum alanine amino transferase (ALT; u/l), creatinin $(\mathrm{mg} / \mathrm{dl})$ according to Reitman and frankel (1957) and total cholesterol (mg/dl) according to Richmond (1973).

The price of producing $1 \mathrm{~kg}$ of meat was calculated by the following equation:

Price to produce $1 \mathrm{~kg}$ of meat $(\mathrm{LE})=$ total feed cost $(\mathrm{LE}) /$ total weight gain $(\mathrm{kg})$ according to Bayoumi (1980).

The data obtained were statistically analyzed using SAS (2004) program with one-way analysis. The experimental model used was as follows:

$$
\mathrm{Y}_{\mathrm{ij}}=\mu+\mathrm{T}_{\mathrm{i}}+\mathrm{e}_{\mathrm{ij}}
$$

Where: $Y_{i j}=$ An observation, $\mu=$ Overall mean, $T_{i}=$ Effect of treatments, $i$ (1 to 5), $\mathrm{e}_{\mathrm{ij}}=$ Experimental error.

Duncan's multiple range test was used to detect any significant differences between the experimental means (Duncan, 1955).

\section{RESULTS AND DISCUSSIONS}

\section{Proximate analysis of citronella by-product $(\mathrm{CBP})$ and clover hay}

Chemical analysis of citronella by- product (CBP) compared to clover hay are presented in Table 2, citronella by product (CBP) contains 91.29\% OM; 5.96\% CP; 36.62\% CF; 3.30\% EE; $45.41 \% \quad$ NFE; $8.71 \%$ ash and $1759 \mathrm{kcal} / \mathrm{kg}$ diet DE. While, the chemical analysis of clover hay is as follows: $91.20 \%, 12.00,30.00 \%, 2.10 \%, 47.10 \%, 8.80 \%$ and 1780 $\mathrm{kcal} / \mathrm{kg}$ for OM, CP, CF, EE, NFE, ash and Digestible energy, respectively according to Feed Composition for Animal and Poultry Feedstuff used in Egypt (RCFF, 2001). This result agrees with Rao et al. (1984) who found that citronella by product contains: $5.40 \% \mathrm{CP} ; 34.20 \% \mathrm{CF}$, and $3.20 \% \mathrm{EE}$. 
Table 2. Chemical composition of citronella by- product and clover hay (on DM basis).

\begin{tabular}{lccccccc}
\hline & \multicolumn{6}{c}{ Chemical analysis\% } & (on DM basis) \\
\cline { 2 - 7 } Items & OM\% & CP\% & CF\% & EE\% & NFE\% & Ash\% & $\begin{array}{c}\text { DE } \\
\text { (Kcal/kg) }\end{array}$ \\
\hline CBP & 91.29 & 5.96 & 36.62 & 3.30 & 45.41 & 8.71 & 1759 \\
$\begin{array}{l}\text { Clover } \\
\text { hay }\end{array}$ & 91.20 & 12.00 & 30.00 & 2.10 & 47.10 & 8.80 & 1780 \\
\hline
\end{tabular}

CBP: Citronella by product

\section{Growth performance}

Effect of different treatments on growth performance of APRI rabbits is shown in Table 3. It is worthy to note that group fed diet containing $40 \%$ $\mathrm{CBP}+\mathrm{E}$ recorded significantly the highest final body weight with a $5.8 \%$ increment comparing to control group. While, group of 20\% CBP recorded the worst value. The same trend was observed in daily weight gain. This improvement of final body weight and daily weight gain in $40 \%$ citronella by product with or without enzyme may be attributed to the growth promoter as reported by Shah et al. (2011) and antimicrobial activity of the effect of residual essential oil such as citral $\alpha$, citral $\beta$, nerolgeraniol, citronellal, terpinolene, geranylmethylheptenone and flavonoids (Lewis, 1986) which has increased when level of citronella by product increased in the diet. These results agree with Podhorsky et al. (1984) who found that addition of citronellyl seneciate to bull calves, heifers, pigs and broilers diets increased growth rates and improved nutrient utilization. Rumokoy et al. (2017) concluded that supplementing Cymbopogonnardus up to $0.5 \%$ to broilers ration had a positive effect in feed intake and live body gain.Feed intake was significantly decreased with $40 \%$ citronella by product with or without enzyme compared to other groups. It was clear that rabbits fed the high levels of CBP consumed lower amount of feed than those fed the low level and control. This may be due to strongly odour of that aromatic plant. In this respect, Salama (2005) found that feed intake was significantly decreased with rabbits fed $9 \%$ geranium by product compared to control.

Regarding to feed conversion ratio (FCR), groups fed $40 \%$ CBP either with or without $\mathrm{E}$ supplementation recorded significantly the best FCR comparing to other groups. In this connection, Mmereole (2010) and Mukhtaret al. (2012) concluded that Cymbopogoncitrates could be used as an alternative to antibiotics. It considered as a practical choice to antibiotics for broilers and acts as growth promoting substance in the poultry, and that 
Table 3. Dietary inclusion of citronella by-product on growth performance of growing rabbits.

\begin{tabular}{|l|c|c|c|c|c|c|}
\hline Items & Control & $\begin{array}{c}\mathbf{2 0 \%} \\
\mathbf{C B P}\end{array}$ & $\begin{array}{c}\mathbf{4 0 \%} \\
\mathbf{C B P}\end{array}$ & $\begin{array}{c}\mathbf{2 0 \%} \\
\mathbf{C B P + E}\end{array}$ & $\begin{array}{c}\mathbf{4 0 \%} \\
\mathbf{C B P}+ \\
\mathbf{E}\end{array}$ & SEM \\
\hline Initial body weight $(\mathrm{g})$ & 703 & 701 & 705 & 700 & 704 & 6.43 \\
\hline Final body weight $(\mathrm{g})$ & $1714^{\mathrm{b}}$ & $1638^{\mathrm{c}}$ & $1718^{\mathrm{b}}$ & $1676^{\mathrm{b}}$ & $1849^{\mathrm{a}}$ & 20.54 \\
\hline Daily weight gain $(\mathrm{g})$ & $18.05^{\mathrm{b}}$ & $16.73^{\mathrm{c}}$ & $18.08^{\mathrm{b}}$ & $17.43^{\mathrm{bc}}$ & $20.45^{\mathrm{a}}$ & 0.36 \\
\hline Daily feed intake $(\mathrm{g})$ & $83.87^{\mathrm{a}}$ & $79.37^{\mathrm{ab}}$ & $72.50^{\mathrm{c}}$ & $81.87^{\mathrm{a}}$ & $75.00^{\mathrm{bc}}$ & 1.26 \\
\hline $\begin{array}{l}\text { Feed conversion ratio } \\
\text { (g feed/g gain) }\end{array}$ & $4.64^{\mathrm{a}}$ & $4.74^{\mathrm{a}}$ & $4.00^{\mathrm{b}}$ & $4.69^{\mathrm{a}}$ & $3.66^{\mathrm{b}}$ & 0.10 \\
\hline
\end{tabular}

$\mathrm{a}, \mathrm{b}$ and $\mathrm{c}$ Means in the same row with different superscripts are significantly different $(\mathrm{P} \leq 0.05)$.

CBP: Citronella by product, $\mathrm{CBP}+\mathrm{E}$ : Citronella by product+ Enzyme mixture

resulted minimized feed expense in the production chain. These improvement in growth performance with $40 \% \mathrm{CBP}+\mathrm{E}$ may be due to enzyme supplementation mixture could support the endogenous enzymes of the poultry \& rabbits (amylase and protease), break down some components of cell wall, which cannot be broken down into absorbable nutrients by endogenous enzymes (Tawfeek, 1996), lowering the gastrointestinal viscosity in digestive tract (Simon, 2000), reduced nutrient entrapment and releasing other nutrients like minerals (Al-Harthi et al., 2009, Soliman et al., 2009 and Ibrahim et al., 2010).This reflects on the rabbit's growth performance (Gharaei et al., 2012).

\section{Nutrients digestibility coefficients}

Results in Table 4 show that all nutrients digestibility coefficient and feeding values were significantly affected by different treatments except dry and organic matter digestibility coefficients. Regarding to crude protein, crude fiber and NFE, groups fed 20\% CBP either without or with E recorded the worst values compared to control and 40\%CBP diets. The reduction in digestion coefficients of $20 \%$ citronella by-product enriched diet without enzyme mix supplementation could be attributed to the high level of nonstarch polysaccharides (NSPs) like cellulose and pentosans (arabinoxlans and glucans) as reported by Mohamed (2003). Ether extract digestibility coefficient was significantly decreased in 20\% CBP compared to other treatments.. Regarding to feeding values of the experimental diets, digestible $\mathrm{CP}$, total digestible nutrients and calculated digestible energy of the diets, all were significantly decreased in $20 \%$ CBP either with or without E. In this respect, El- Manylawi and El-Banna (2013) reported that replacing clover hay with either $10 \%$ or $20 \%$ date stone meal + Allzyme ${ }^{\circledR}$ SSF to the rabbits diets 
Table4. Dietary inclusion of citronella by-product on nutrients digestibility coefficients and feeding values of growing rabbits.

\begin{tabular}{|c|c|c|c|c|c|c|}
\hline Items & Control & $\begin{array}{l}20 \% \\
\text { CBP }\end{array}$ & $\begin{array}{l}40 \% \\
\text { CBP }\end{array}$ & $\begin{array}{c}20 \% \\
\text { CBP+E }\end{array}$ & $\begin{array}{c}40 \% \\
\text { CBP +E }\end{array}$ & SEM \\
\hline \multicolumn{7}{|l|}{ Digestibility coefficients (\%) } \\
\hline Dry matter (DM) & 65.13 & 61.21 & 64.51 & 64.43 & 65.51 & 2.03 \\
\hline Organic matter (OM) & 63.40 & 59.44 & 63.31 & 61.10 & 65.77 & 2.23 \\
\hline Crudeprotein $(\mathrm{CP})$ & $76.34^{2}$ & $68.72^{\mathrm{c}}$ & $74.49^{\mathrm{ab}}$ & $70.76^{6 c}$ & $77.10^{2}$ & 1.08 \\
\hline Crude fiber (CF) & $40.0^{25}$ & $30.33^{\mathrm{c}}$ & $37.45^{6}$ & $32.12^{c}$ & $43.66^{2}$ & 1.47 \\
\hline Ether extract (EE) & $83.41^{\mathrm{a}}$ & $78.68^{\circ}$ & $82.70^{2 b}$ & $82.21^{\text {sb }}$ & $85.30^{2}$ & 0.87 \\
\hline Nitrogen free extract (NFE) & $77.21^{\mathrm{a}}$ & $69.21^{\circ}$ & $75.32^{\mathrm{sb}}$ & $72.43^{b c}$ & $78.21^{\mathrm{s}}$ & 0.96 \\
\hline \multicolumn{7}{|l|}{ Feeding values } \\
\hline Digestible crude protein (\%) & $13.39^{\mathrm{a}}$ & $12.04^{\mathrm{b}}$ & $12.97^{\mathrm{a}}$ & $12.40^{6}$ & $13.43^{\mathrm{a}}$ & 0.15 \\
\hline Total digestible nutrients $(\%)$ & $59.01^{\text {sb }}$ & $54.43^{\mathrm{c}}$ & $58.76^{6}$ & $56.31^{\mathrm{be}}$ & $61.12^{2}$ & 0.75 \\
\hline Digestible energy (kcal/kg) & $2614.14^{b}$ & $2411.2^{c}$ & $2603^{b}$ & $2494.5^{c}$ & $2707.6^{\mathrm{a}}$ & 29.01 \\
\hline
\end{tabular}

a, $b$ and $c$ Means in the same row with different superscripts are significantly different $\left(\mathrm{P}_{\leq} 0.05\right)$.

*DE = TDN X 44.3 (Schneider and Flatt, 1975).

$\mathrm{CBP}$ : Citronella by product, $\mathrm{CBP}+\mathrm{E}$ : Citronella by product + Enzyme mixture

resulted in numerical increases in the digestibilities of most nutrients compared to the other tested diets included the control. Also, Salama et al. (2019) noted that control group recorded higher digestibility coefficient of $\mathrm{CP}, \mathrm{CF}, \mathrm{EE}$ and NFE without significant differences to groups of either 20or $40 \%$ fennel seed meal + enzyme mix.In current study, improving digestion coefficient and nutritive values for groups fed diets supplied with enzyme mix could be due to supporting the growth of beneficial bacteria in the gut (Kholif et al., 2005 and Viveroset al., 1993). Reducing digestive tract viscosity by hydrolyzing part of none starch polysaccharides (Bedford and Classen, 1992). Hence, improving nutrient utilization (Choctet al., 1999).

\section{Carcass characteristics}

As shown in Table 5 group of $40 \%$ CBP with or without E recorded higher carcass $\%$ without significant variation to control followed by those fed $20 \% \mathrm{CBP}+\mathrm{E}$ and the lowest value was recorded for group of $20 \% \mathrm{CBP}$.

Regarding to dressing \%, control, groups of $40 \%$ CBP with or without E recorded higher percentage without significant differences to other fed $20 \%$ $\mathrm{CBP}+\mathrm{E}$ and control. While, rabbits fed 20\% CBP recorded the lowest dressing $\%$. The rest of carcass measurements (liver, kidney, heart and giblets) were not significantly affected by dietary treatments. In this context, Salama (2005) who found that incorporation of 6 or $9 \%$ geranium by product in rabbit diets gave the best values of carcass and dressing percentage. Salama et al. (2019) who found that replacement up to $40 \%$ fennel meal plus enzyme mix instead of clover hay led to insignificant differences in rabbits carcass and dressing 
Table 5. Dietary inclusion of citronella by-product on carcass characteristics of growing rabbits.

\begin{tabular}{|l|c|c|c|c|c|c|}
\hline $\begin{array}{l}\text { Items } \\
(\%)\end{array}$ & Control & $\begin{array}{c}\mathbf{2 0 \%} \\
\mathbf{C B P}\end{array}$ & $\begin{array}{c}\mathbf{4 0 \%} \\
\mathbf{C B P}\end{array}$ & $\begin{array}{c}\mathbf{2 0 \%} \\
\mathbf{C B P}+\mathbf{E}\end{array}$ & $\begin{array}{c}\mathbf{4 0 \%} \\
\mathbf{C B P}+\mathbf{E}\end{array}$ & SEM \\
\hline Carcass & $53.22^{\mathrm{ab}}$ & $50.30^{\mathrm{c}}$ & $53.41^{\mathrm{ab}}$ & $52.79^{\mathrm{b}}$ & $54.65^{\mathrm{a}}$ & 0.41 \\
\hline Liver & 2.92 & 2.83 & 3.03 & 2.88 & 3.25 & 0.07 \\
\hline Kidney & 0.610 & 0.558 & 0.603 & 0.596 & 0.662 & 0.01 \\
\hline Heart & 0.371 & 0.358 & 0.367 & 0.363 & 0.392 & 0.01 \\
\hline Giblets * & 3.90 & 3.74 & 4.00 & 3.83 & 4.30 & 0.09 \\
\hline Dressing ** & $57.12^{\mathrm{a}}$ & $54.04^{\mathrm{b}}$ & $57.41^{\mathrm{a}}$ & $56.62^{\mathrm{ab}}$ & $58.95^{\mathrm{a}}$ & 0.49 \\
\hline
\end{tabular}

$\mathrm{a}, \mathrm{b}$ and $\mathrm{c}$ Means in the same row with different superscripts are significantly different $(\mathrm{P} \leq 0.05)$.

$*$ Giblets $\%=$ Liver $\%+$ Kidney $\%+$ Heart $\%$, ** Dressing $\%=$ Carcass $\%+$ Giblets $\%$. CBP: Citronella by product, $\mathrm{CBP}+\mathrm{E}$ : Citronella by product+ Enzyme mixture

percentages. The enhancement in carcass and dressing percentages due to enzymes mix addition was reported by Ibrahim et al. (2010) on growing rabbits and Khidret al. (2005) on turkey chicks.

\section{Blood measurements}

As shown in Table 6. Rabbits fed different treatments did not show any significant variations in serum total protein, albumin and creatinine between them. concerning serum AST, rabbits fed $20 \%$ CBP with or without E and $40 \% \mathrm{CBP}+\mathrm{E}$ recorded significantly higher values than control and $40 \% \mathrm{CBP}$. While, rabbits fed 20\% CBP+E recorded significantly lower ALT values comparing to all groups except group of $40 \% \mathrm{CBP}$.

Table 6. Dietary inclusion of citronella by-product on blood constituents of growing rabbits.

\begin{tabular}{|l|c|c|c|c|c|c|}
\hline Items & $\begin{array}{c}\text { Contr } \\
\text { ol }\end{array}$ & $\begin{array}{c}\mathbf{2 0 \%} \\
\text { CBP }\end{array}$ & $\begin{array}{c}\mathbf{4 0 \%} \\
\mathbf{C B P}\end{array}$ & $\begin{array}{c}\mathbf{2 0 \%} \\
\mathbf{C B P}+\mathbf{E}\end{array}$ & $\begin{array}{c}\mathbf{4 0 \%} \\
\mathbf{C B P}+\mathbf{E}\end{array}$ & SEM \\
\hline Total protein ( g/dl) & 6.40 & 5.74 & 6.53 & 6.63 & 6.33 & 0.25 \\
\hline Albumin ( g/dl) & 4.94 & 5.10 & 4.43 & 4.93 & 5.30 & 0.13 \\
\hline AST(U/L) & $34.36^{\mathrm{b}}$ & $39.23^{\mathrm{a}}$ & $32.20^{\mathrm{b}}$ & $40.43^{\mathrm{a}}$ & $38.22^{\mathrm{a}}$ & 0.88 \\
\hline ALT(U/L) & $55.59^{\mathrm{a}}$ & $53.43^{\mathrm{a}}$ & $46.43^{\mathrm{bc}}$ & $41.83^{\mathrm{c}}$ & $51.20^{\mathrm{ab}}$ & 1.44 \\
\hline Creatinine (mg/ dl) & 1.29 & 1.92 & 1.81 & 1.56 & 1.40 & 0.10 \\
\hline $\begin{array}{l}\text { Total cholesterol } \\
\text { (mg/ dl) }\end{array}$ & $96.14^{\mathrm{a}}$ & $79.18^{\mathrm{b}}$ & $73.80^{\mathrm{b}}$ & $75.83^{\mathrm{b}}$ & $71.85^{\mathrm{b}}$ & 2.55 \\
\hline
\end{tabular}

$\mathrm{a}, \mathrm{b}$ and $\mathrm{c}$ Means in the same row with different superscripts are significantly different $(\mathrm{P} \leq 0.05)$.

CBP: Citronella by product, $\mathrm{CBP}+\mathrm{E}$ : Citronella by product+ Enzyme mixture 
All tested groups recorded significantly lower serum total cholesterol rather than control group. The antioxidant properties in CBP may be responsible for reducing rabbit's blood total cholesterol as documented by Ruberto et al. (2000). Salama (2005) found that inclusion of 3, 6 or $9 \%$ geranium and spearmint by products in rabbit diets reduced total cholesterol. The same conclusion was observed by Salama et al. (2019) who found that rabbits fed diets containing fennel seed meal without or with enzyme mix achieved significantly lower serum total cholesterol than un-treated group.

\section{Economical evaluation}

Cost of producing one kilogram meat is elaborated in Table 7. all of the tested diets recorded lower feed cost than control especially 40\% CBP (17.78 $\mathrm{LE})$ followed by $40 \% \mathrm{CBP}+\mathrm{E}(18.69 \mathrm{LE})$ as they reduced meat production cost. The decrease in clear in $40 \% \mathrm{CBP}+\mathrm{E}$ (16.32. LE), followed by $40 \%$ CBP (17.56 LE) and 20\% CBP (21.41LE) then 20\% CBP+E (21.50 LE), as compared to control $(21.56 \mathrm{LE})$. It is noticed that net revenue $(\mathrm{LE})$ for diets, economic efficiency and relative economic efficiency increased with $40 \%$ CBP $+E$ followed by $40 \%$ CBP. Salama (2005) found that replacement of 6

Table 7. Dietary inclusion of citronella by-product on producing $1 \mathrm{~kg}$ meat of growing rabbits and Economic efficiency.

\begin{tabular}{|c|c|c|c|c|c|}
\hline Items & Control & $\begin{array}{l}20 \% \\
\text { CBP }\end{array}$ & $\begin{array}{l}40 \% \\
\text { CBP }\end{array}$ & $\begin{array}{c}20 \% \\
\text { CBP } \\
+E\end{array}$ & $\begin{array}{c}40 \% \\
\text { CBP } \\
+E\end{array}$ \\
\hline Price of $1 \mathrm{~kg}$ diet & 4.643 & 4.510 & 4.380 & 4.580 & 4.450 \\
\hline Total feed intake $(\mathrm{Kg})$ & 4.696 & 4.444 & 4.060 & 4.585 & 4.200 \\
\hline Total feed cost/rabbit (LE)(B) & 21.80 & 20.04 & 17.78 & 20.99 & 18.69 \\
\hline Total weight gain $(\mathrm{Kg})$ & 1.011 & 0.936 & 1.012 & 0.976 & 1.145 \\
\hline Price of $1 \mathrm{~kg}$ meat (LE) & 21.56 & 21.41 & 17.56 & 21.50 & 16.32 \\
\hline Price of $1 \mathrm{~kg}$ body weight & 45 & 45 & 45 & 45 & 45 \\
\hline Selling price/rabbit (LE) (A) & 45.49 & 42.12 & 45.54 & 43.92 & 51.52 \\
\hline Net revenue $(\mathrm{LE})^{1}$ & 23.69 & 22.08 & 27.76 & 22.93 & 32.85 \\
\hline Economic efficiency $^{2}$ & 108.66 & 110.17 & 156.13 & 109.24 & 175.76 \\
\hline Relative Econ. Eff. $^{3}$ & 100 & 101.38 & 143.68 & 100.53 & 161.75 \\
\hline
\end{tabular}

Price to produce $1 \mathrm{~kg}$ of meat $(\mathrm{LE})=$ total feed cost $(\mathrm{LE}) /$ total weight gain $(\mathrm{kg})$.

(1) Net revenue $=\mathrm{A}-\mathrm{B}$.

(2) Economic efficiency $=(\mathrm{A}-\mathrm{B} / \mathrm{B} \times 100)$.

(3) Relative Economic Efficiency= Economic efficiency of treatments other than the control/ Economic efficiency of the control group CBP: Citronella by product, $\mathrm{CBP}+\mathrm{E}$ : Citronella by product + Enzyme mixture 
or $9 \%$ geranium by products in rabbit diets gave the best economical efficiency. El- Manylawi and El-Banna (2013) who found that supplementing Allzyme ${ }^{\circledR}$ SSF (a commercial enzyme mix) in rabbit diets containing $10 \%$ date stone meal recorded better economical efficiency compared to control group. Also, Salama et al. (2019) came to the same conclusion with adding Natuzyme fortified (enzyme mix) to $10.8 \%$ fennel seed meal of the whole diet gained more economical efficiency than control group (fed diet containing clover hay).

Conclusively, inclusion of citronella by-product as a new and cheap ingredient at $40 \%$ instead of clover hay added with or without enzyme mixture, resulted in enhancing growth performance, carcass traits, nutrient digestibility coefficients and economic efficiency of growing APRI rabbits.

\section{REFERENCES}

A.O.A.C. (2000). Official Methods of Analysis. $17^{\text {th }}$ ed., Published by the A.O.A.C., Washington, D.C. USA.

Agriculture ministry decree (1996). The standard properties for ingredients, feed additives and feed manufactured for animal and poultry. El-Wakaee El-Masria, Amirria Press, Cairo, Egypt. No.192, pp:95.

Al-Harthi, M. A., A. A. El-Deek, H. M. Yakout, and Al-Refaay, M. (2009). The Nutritive Value ofDate Waste Meal as a Feedstuff for Lohmann Brown Pullets and Layers. Japan Poultry Science Journal, 46 (4): 303-312.

Bayoumi , S.B.(1980). Effect of different rations on egg production for breeding hens. M.Sc. Thesis, Faculty of. Agriculture Kafr-Elsheikh, Tanta University, Egypt.

Bedford, M.R. and Classen, H. L. (1992). Reduction of intestinal viscosity through manipulation of dietary rye and pentosanase concentration is affected through changes in the carbohydrate composition of the intestinal aqueous phase and results in improved growth rate and food conversion efficiency of broiler chicks. J. Nutr., 122: 560-569.

Cheeke, P.R. (1987). Rabbit Feeding And Nutrition. Academic Press Orlando, Florida, USA, 376 p. 
Choct, M.; Hughes, R. J. and Bedford, M.R. (1999). Effects of xylanase on individual bird variation, starch digestion throughout the intestine and ilealandcaecal volatile fatty acid production in chickens fed wheat. Br. Poultry Sci., 40: 419-422.

Duncan, D.B.(1955). Multiple range and multiple F tests. Biometrics, 11: $1-42$.

Prabuseenivasan S.,Jayakumar M. andIgnacimuthu S. (2006).In vitro antibacterial activity of some plant essential oils. $B M C$ Complementary and Alternative Medicine , 6 (1):39-46.

El-Manylawi M. A. and El-Banna H. M. (2013).Effect of feeding date stone meal supplemented with allzyme ${ }^{\circledR}$ on performance of growing new zealand rabbits. Egyptian J. Anim. Prod. (2013) 50(2):103-109.

Gharaei, M. A.; Dastar, B.; Nameghi, A. H.; Tabar, G. H.; and Shargh, M. S. (2012). Effects of guar meal with and without betamannanas enzyme on performance and immune response of broiler chicks. Int. Res. J. Appl. Basic Sci, 3: 2785-2793.

Ibrahim, M. R., H. M. El-Banna, and El-Manylawi , M. A. (2010). Evaluating utilization of ground date stone meal with or without kemzyme in the diets of growing New Zealand rabbits. IV International Date Palm Conference, 15-17 March, 2010, Abu Dubi, UAE. Acta Hort. (ISHS) 882:691-697 http://www .actahort. org/books / 882 / 882 75.htm.

Khidr, R. E., A. Z. Soliman, and ElShoukiery, N. A. (2005). Effect of using date stone meal without or with kemzyme supplementation on productive performance and carcass characteristics of growing turkey. Egyptian Journal. of Desert Research, 55: 1-18.

Kholif, A.M.; El-Ashry, M.A; El-Alamy, H.A; El-Sayed, H.M.; Fadel, M. and Kholif, S. (2005).Biological treatments banana wastes for feeding lactating goats. Egyptian Journal Nutrition and Feeds, 8: 149-162.

Lewis WH (1986). The useful plants of west tropical Africa. Economic Botany, 40: 176-178.

Manurung R. , Melinda R. , Abduh M. Y., Widiana A., Sugoro I and Suheryadi D.(2015). Potential Use of Lemongrass (Cymbopogon winterianus) Residue as Dairy Cow Feed. Pakistan Journal of Nutrition, 14 (12): 919-923.

Mmereole F.U. (2010). Effects of lemon grass (Cymbopogoncitratus) leaf meal feed supplement on growth performance of broiler chicks. International Journal of Poultry Science, 9:1107-1111. 
Mmereole F.U.C. (2010). Effects of lemmon grass (Cymbopogoncitratus) leaf meal feed supplement on growth performance of broiler chicks. Inter. Journal of Poultry Science, 9(12): 1107-1111.

Mohamed, Y. (2003).Studies on the utilization of some medicinal and aromatic plants processing wastes in rabbit feeding. M.Sc Institute of Environmental Studies and Research. Ain Shams University.

Mukhtar A.M., Mohamed ,K.A.; Amal, O.A, Ahlam, (2012). Effect of different levels of lemon grass oil (LGO) as a natural growth promoter on the performance, carcass yields and serum chemistry of broiler chicks. Egyptian Poultry Science, 33: 1-7.

Mukhtar, A.M; Mohamed, K.A.; Amal, O.A and Ahlam, A.H. (2012). Effect of different levels of lemon grass oil as anatural growth promoter on the performance, carcass yields and serum chemistry of broiler chicks. Egyptian Poultry Science 33:1-7.

Nakahara K.; Alzoreky N. S.; Yoshihashi T.; Nguyen H.T.T.; Trakoontivakorn G. (2003). Chemical Composition and Antifungal Activity of Essential Oil from Cymbopogon nardus (Citronella Grass). Japan Agricultural Research Quarterly, 37 (4): 249-252.

Paranagama P.; Abeysekera T.; Nugaliyadde L. and Abeywickrama, K. (2003). Effect of the essential oils of Cymbopogoncitratus, C. nardus and Cinnamomumzeylanicum on pest incidence and grain quality of rough rice (paddy) stored in an enclosed seed box. Food, Agriculture \& Environment., 1(2): 134-136.

Podhorsky ,M. ; Z., Cvak.; Z., Kezlinek, and Z. Sova (1984). Utilization of citronellyl Seneciate in the food industry and animal production to stimulate microbial cultures and detoxify mycotoxins and pesticides in feeds for farm animal. Ved-a-Vyzk-um-V-PotavinarskemPrumyslu, .30:289-308.(Abstract).

Rao, A.S.; K. Sundareshan; U. Prabhu and S.R. Sampath (1984).Chemical composition and nutritive value of spent citronella grass and cottonseed hulls. Indian J. Animal-Science, 54:11, 10641065.

RCFF; Regional Center for Food and Feed (2001). Feed Composition Tables For Animal and Poultry Feedstuffs Used In Egypt, Technical Bulletin No.1, Ministry of Agriculture, Egypt.

Reitman S. and Frankel S. (1957). A colorimetric method for the determination of serum glutamic oxalacetate and glutamic pyruvic transaminases. Am. J. Clin. Path. 28: 56-63. [PubMed], [Web of Science (®], [Google Scholar]Am. J. Clin. Path., 28:56-63. 
Richmond W. (1973). Preparation and Properties of a Cholesterol Oxidase from Nocardia sp. and Its Application to the Enzymatic Assay of Total Cholesterol in Serum. Clinical Chemistry, Volume 19, Issue 12, 1 December 1973, Pages 1350-1356, https://doi.org/ 10.1093/ clin chem /19. 12.1350

Rosete, A.; Soto, R.; Vega, G.; Alvarex, M. and Rivas, J. L. (1987). Feeding of heifers with forage residues from steam distillation of citronella (Cymbopogonwinteranus Jowitt) and Lemon-scented bontanicals . LebensmittelWissenschaft- und-Technologie. 35(4), 319-324.

Ruberto, G.; Baratta, M. T.; Deans, S.G. and Dor-Man, H.J. (2000). Antioxidant and antimicrobial activity of FoeniculumVulgare and maritimum essential oils. Planta Med., 66 (8): 687- 693.

Rumokoy L. ; Kaunang C. and Toar W. (2017).Effects of citronella oil extract of Cymbopogonnardus L. on contact frequency proportion of Muscadomestica L. (Diptera:Muscidae) in ration and broilers performance. Indonesian Journal of Entomology, 14 (2): 89-96.

Salama W.A. (2005).Performance of growing rabbits fed diets containing by- products of geranium and spearmint. MS.C., Cairo University

Salama W.A.; Refaie A.M. and El-Shora, M. A. (2019). Performance of growing rabbits fed diets containing fennel seed meal without or with enzyme mixture. Egyptian Journal of Rabbit Science, 29 (1): 45 -60 .

SAS (2004).SAS/DSTAT User's Guide: Statistics, Release 6.04, SAS Institute, Inc., Cary, NC., USA.

Schneider, B.H. and W.P. Flatt (1975). The Evaluation of feed through Digestibility experiments. University of Georgia Press Athens, Georgia, USA.423p.

Shah, G.; Shri, R.; Panchal, V.; Sharma, N.; Singh, B. and Mann A. S. (2011). Scientific basis for the therapeutic use of Cymbopogon citrates, stapf (Lemon grass). Journal of Advanced Pharmaceutical Technology \& Research, 2(1): 3-8.

Simon, O. (2000). Non starch polysaccharides (NSP) hydrolyzing enzyme as feed additions. Male of action in the gastro intestinal tract. Lohman Information, 23: 7-13.

Soliman, A. Z. M.; Khidr, R. E; ELManylawi, M. A. F and El-Sheikh, S. E. M. (2009). Chemical and biological evaluation of date stone meal as an untraditional feedstuff in growing rabbit diets. The 5th International Poultry Conference 10-13 March 2009. Taba -Egypt (852-863). 
Tawfeek, M. I. (1996). Effect of feeding system and supplemented diet with Alltech ${ }^{\circledR}$ enzyme on growth, blood constituents, carcass traits and reproductive performance in rabbits under intensive production conditions. Egyptian Journal of Rabbit Science, 6: 21 - 37.

Viveros, A.; Brenes, A.; Pizarro, M. and Castano, M. (1993). Effect of enzyme supplementation of a diet based on barley and autoclave treatment on apparent digestibility, growth performance and gut morphology of broilers. Animal Feed Science And Technology. 48(3/4):237-251.

\section{التأثير الغذائى لأستخدام مخلف حشيشة السترونيلا مع أو بلون مخلوط الايزيمات على الاداء الانتاجى للأرانب الناميه.}

أميره محمود رفاعى - ولاء عطيه سلامه ـ ـ محمد أحمد الثورة ـ فاطمة جلال أحمد

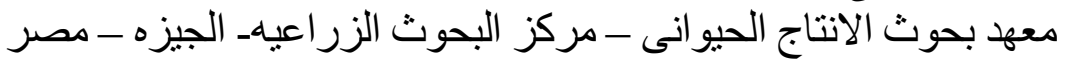

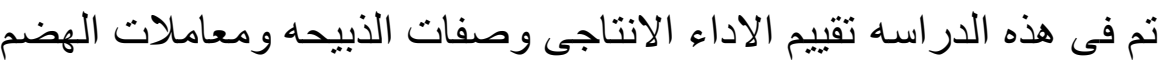

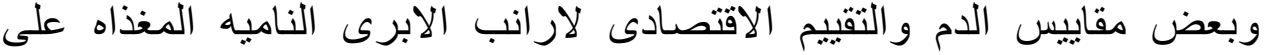

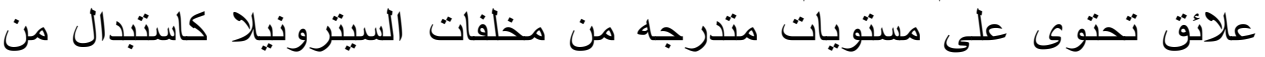
دريس البرسيم خلال فترةالنمو والتى استمرت لمدة 8 أسابيع. استخدم عدد 80

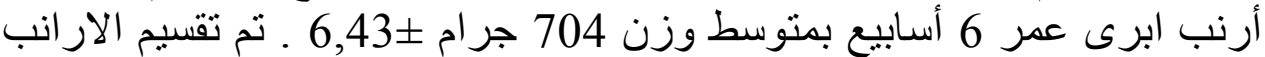
عشو ائيا الى 5 مجمو عات بكل منها 16 أرنب أرنب مقسمه الى 4 ألى مكرر ات ات بكل مكررة 4 أر انب. تغذت المجمو عه الاولى على عليقة قاعديه (مجمو عة المقارنه) وتغذت الت

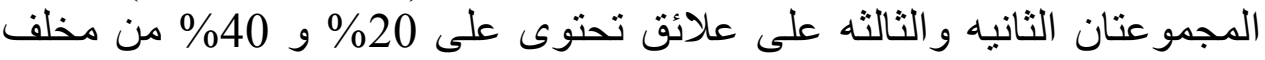
السيترونيلا كاستبدال من دريس البرسيم حيث مثلت 5,86\% و 11.72\% من ع

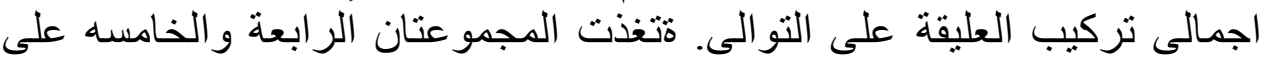

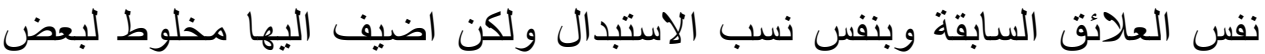

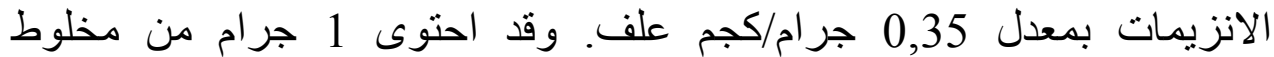

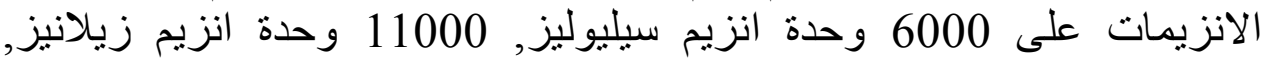
1500 وحدة انزيم فيتيز, 700 وحدة انزيم الفا اميليز, 700 وحدة وحدة انزيم بينا

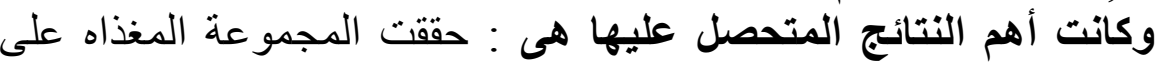
40\% مخلف السيترونيلا + مخلوط الانزيم أعلى وزن هي هي نهائى بمعدل

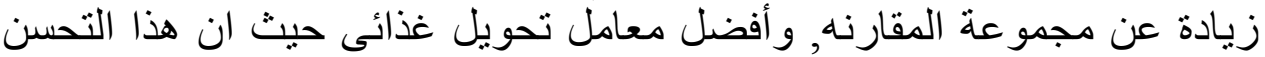




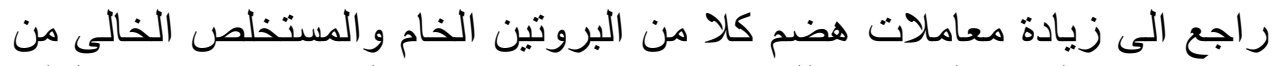

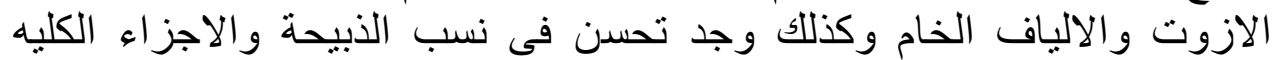
المأكوله بالاضافة لتحقيق ارخص سعر لكليوجرام من اللحم و أعلى كفاءة أقتصادية.

التوصية: يمكن ان نستخلص من هذه الاراسه انه يمكن احلال مخلف

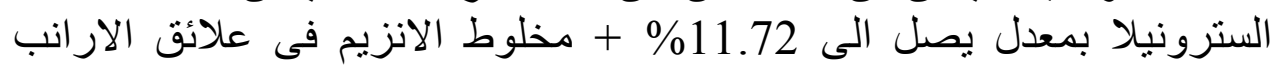
النامبه والذى ادى الى تحسين الاداء الانتاجى و الكفاءة الاقتصادية 